Review article

\title{
Homeopathy in parasitic diseases
}

\author{
Denise Lessa Aleixo¹, Leoni Villano Bonamin², Fabiana Nabarro Ferraz \\ Franciele Karina da Veiga ${ }^{1}$, Silvana Marques de Araújo ${ }^{1}$
}

${ }^{1}$ Universidade Estadual de Maringá, Maringá, Brazil

${ }^{2}$ Universidade Paulista, São Paulo, Brazil

\begin{abstract}
Background: The use of homeopathic medicines has increased, partly because conventional drugs do not always elicit the desired effects, and partly because their side effects might compromise the patient's' adherence to treatment. Several studies showed benefits in the use of highly diluted medicines for the treatment of infectious diseases. Aim: The aim of the present review was to perform a critical discussion about aspects of homeopathy and the current status of veterinary experimentation, as well as of the use of highly diluted drugs in infectious and parasitic diseases. The main aspects of effects, therapeutic regimens and / or dynamizations used in various models are discussed. Methods: Articles published since 2000 in journals included in databases PubMed and SciELO and specialized journals sought for and reviewed using keywords "parasitic diseases/homeopathy" and "parasitic diseases/ ultra-dilutions". Results: Several recent experimental studies demonstrated the biological effect of highly diluted medications on parasitic infections, with reduction of the number of parasites and improvement of the clinical condition of the affected animals. Several articles exhibit problems in the description of methods, which threaten the reproducibility of experiments. Conclusion: The acknowledgment of homeopathy depends on the credibility of investigators. Although research on homeopathy has clearly increased in recent years, relative to both implementation of more consistent methods and description of data and methods, improvement is still required. Precise and detailed descriptions will contribute to advance the use of homeopathy, so that society at large might benefit in actual practice,
\end{abstract}

Keywords: homeopathy, parasitic infections, CAM (complementary and alternative medicine).

\section{Introduction}

Homeopathic medicines, ultra-diluted or ultra-molecular compounds,and "dynamized" systems are synonyms used to name preparations that are manipulated in compliance with the homeopathic pharmacopeia[1]. According to the latter, homeopathic medicine is "any form of pharmaceutical dispensation administered in accordance with the principle of similarity and/or identity, with curative and /or preventive purposes. Homeopathic medicines are prepared by means of the dynamization technique and [might be indicated] for internal or external use".

The homeopathic literature mentions a wide variety of medicines, including so-called "constitutional medication", "isotherapic agents", "nosodes", "sarcodes", "organotherapic agents", and so forth, all of them prepared according to the homeopathic pharmacopoeia, the concentration of which may or not exceed Avogadro's number. 
The connection between homeopathy and parasitology dates from the $18^{\text {th }}$ century, ever since Christian Friedrich Samuel Hahnemann (1755-1843), considered as the "father of homeopathy", self-administered Cinchona officinalis, a substance used at the time for the treatment of malaria. In this experiment, Hahnemann observed that the symptoms elicited by this substance on him were similar to the ones y malaria. Based on those observations, Hahnemann established the principles that define homeopathy and that differ from the ones of conventional medicine, to wit: therapeutic similarity (similia similibus curentur), which means that diseases can be treated with substances that elicit symptoms similar to the ones of the disease to treat; use of infinitesimally diluted doses; compliance with the patient's individuality; and in systemic approach to treatment [2].

Such integrated notion refers to the one of organic homeostasis, which is altered in parasitic diseases as a reflect of the imbalance in the parasite-host relationship, which must be balanced to benefit the host.

The use of homeopathic medicines has increased, partly because conventional drugs do not always elicit the desired effects, and partly because their side effects compromise the patient's adherence to treatment.

A frase abaixo ficou sem sentido! Por favor, reescrever!

For infectious agents in general, many reports can be found in the literature. According to some authors [3-7], the clinical use follows the same pattern, including worldwide and national policies to increase their use[8,9].

In agriculture and cattle-farming, the advances in the use of homeopathy areis well established. In some countries, national policies [10] include the use of homeopathic medicines in systems of organic productions [11].

In regard to fundamental research in parasitology, several experimental models based on the induction of infection/infestation by parasites have been established. These models are excellent tools to evaluate the efficacy and mechanism of action of new medicines in both mass oreither mass or highly diluted doses.

The aims of the present study was to perform a systematic review about aspects of homeopathy in parasitic diseases, to evaluate the use of highly diluted drugs in parasitic infections and the main aspects of effects, therapeutic regimens and / or the dynamizations used in various models.

\section{Methods}

For the purpose of the present review, a survey of articles published from 2000 onwards was conducted in journals included in database PubMed/Medline and SciELO. We also looked for studies published in conference annals. The keywords used were "parasitic diseases/homeopathy" and "parasitic diseases/ultradilutions", in English and Portuguese.

Specialized journals such as Homeopathy, International Journal of High Dilution Research, and Brazilian Homeopathic Journal were also used. The content of each issue of these journals was surveyed for articles that addressed subject "use of highly diluted medication in parasitic infections".

The articles were entered in tables according to subject: use of homeopathic medicines in used to treat arthropod infestations; use of homeopathic medicines in the treatment helminthiasis; and use fof homeopathic medicines in the treatment of diseases caused by protozoa. 
.The studies were further subjected to critical analysis based on criteria formulated for fundamental research in homeopathy[12] and listed in REHBaR [13].] to help investigators plan experiments and present their results.

\section{Results}

Almost 50 articles were screened and assessed for eligibility, and 39 were included in the present review. The articles that did not comply with the criteria applied, as e.g., as year of publication, were excluded. The results of the included studies are presented in tables that include the relevant data and citation.

Highly diluted medications for treatment of parasitic diseases

Several recent experimental studies demonstrated the biological effect of highly diluted medications on parasitic infections (Tables 1-3). Parallel to such scientific studies, the practical application of homeopathic products to veterinary medicine, especially in cattle farming, has recently consolidated. Currently, homeopathic products are used in animal husbandry worldwide, due to their benefits in the control of diseases, including endo- and ectoparasites, as well as to improve the animals' productivity in an environmentally safe manner $[3,4,14,15]$.

Similarly, also in the use of homeopathic products has been shown to improve productivity and the control of insects and plagues without causing environmental impacts, thus contributing to sustainable development and environmental protection as a whole[16]. 
Table 1: Use of homeopathic medication to treat arthropod infestations

\begin{tabular}{|c|c|c|c|c|c|}
\hline PARASITE & $\begin{array}{l}\text { MEDICATION* } \\
\text { (POTENCY) }\end{array}$ & $\begin{array}{l}\text { ANIMAL MODEL } \\
\text { (AGE) }\end{array}$ & TREATMENT REGIMENS & EFFECT & REFERENCE \\
\hline $\begin{array}{l}\text { Rhipicephalus } \\
\text { (Boophilus) } \\
\text { microplus }\end{array}$ & $\begin{array}{l}\text { Factor C\&MC } \\
\text { Biotherapic } 12 \mathrm{CH} \\
\left(10^{-12}\right)\end{array}$ & $\begin{array}{l}\text { bovine } \\
\text { (different ages) }\end{array}$ & $\begin{array}{l}400 \mathrm{~g} \text { mixed with the mineral salt } \\
\text { ad libitum for } 24 \text { months. }\end{array}$ & $\downarrow$ number of parasites & $\begin{array}{l}\text { Arenales and } \\
\text { Coelho, } 2002\end{array}$ \\
\hline $\begin{array}{l}\text { Dermatobia } \\
\text { hominis }\end{array}$ & $\begin{array}{l}\text { Isotherapic } \\
12 \mathrm{DH}\left(10^{-12}\right)\end{array}$ & $\begin{array}{l}\text { bovine } \\
\text { (age not provided) }\end{array}$ & $\begin{array}{l}\text { Mixed with the mineral salt (ad } \\
\text { libitum) for } 35 \text { days. }\end{array}$ & $\begin{array}{l}\downarrow \text { size of lesions } \\
\text { Interrupted the life-cycle } \\
\text { of the parasite. }\end{array}$ & $\begin{array}{l}\text { Fonseca and } \\
\text { Goloubeff, } 2006\end{array}$ \\
\hline $\begin{array}{l}\text { Rhipicephalus } \\
\text { (Boophilus) } \\
\text { microplus }\end{array}$ & $\begin{array}{l}\text { Factor C\&MC*} \\
\text { Biotherapic } \\
12 \mathrm{CH}\left(10^{-24}\right)\end{array}$ & $\begin{array}{l}\text { bovine } \\
\text { (360-420 days old) }\end{array}$ & $\begin{array}{l}1.6 \mathrm{~g} / \text { animal/ day mixed with the } \\
\text { mineral salt (ad libitum). }\end{array}$ & $\downarrow$ number of parasites & Silva et al., 2008 \\
\hline \multirow{3}{*}{$\begin{array}{l}\text { Rhipicephalus } \\
\text { (Boophilus) } \\
\text { microplus }\end{array}$} & $\begin{array}{l}\text { Biotherapic } \\
12 \mathrm{CH}\left(10^{-24}\right)\end{array}$ & \multirow{3}{*}{$\begin{array}{l}\text { bovine } \\
\text { (age not provided) }\end{array}$} & $\begin{array}{l}\text { Mixed with the mineral salt (ad } \\
\text { libitum) for } 6 \text { months. }\end{array}$ & \multirow{3}{*}{$\begin{array}{l}\downarrow \text { number of parasites } \\
\downarrow \text { size of the parasites }\end{array}$} & \multirow[t]{3}{*}{ Gazim et al.,2010 } \\
\hline & & & & & \\
\hline & $\begin{array}{l}\text { Biotherapic } 30 \mathrm{CH} \\
\left(10^{-60}\right)\end{array}$ & & $\begin{array}{l}\text { Beginning of treatment }-6 \text { months } \\
\text { after Biotherapic } 12 \mathrm{cH} \text { on alternate } \\
\text { days. }\end{array}$ & & \\
\hline $\begin{array}{l}\text { Rhipicephalus } \\
\text { (Boophilus) } \\
\text { microplus }\end{array}$ & $\begin{array}{l}\text { Factor C\&MC*} \\
\text { Biotherapic } \\
12 \mathrm{CH}\left(10^{-12}\right)\end{array}$ & $\begin{array}{l}\text { bovine } \\
\text { (age not provided) }\end{array}$ & $\begin{array}{l}5 \mathrm{~g} \text { mixed with the mineral salt ad } \\
\text { libitum }\end{array}$ & $\begin{array}{l}\downarrow \text { number of ectoparasites } \\
\downarrow \text { number of intestinal } \\
\text { parasites } \\
\downarrow \text { eggs/g of feces }\end{array}$ & Signoretti et al.,2010 \\
\hline $\begin{array}{l}\text { Rhipicephalus } \\
\text { (Boophilus) } \\
\text { microplus }\end{array}$ & $\begin{array}{l}\text { Biotherapic 12DH } \\
\left(10^{-12}\right)\end{array}$ & \multirow[t]{2}{*}{$\begin{array}{l}\text { bovine } \\
\text { (age not provided) }\end{array}$} & $\begin{array}{l}2 \mathrm{~mL} \text { mixed with the mineral salt for } \\
\text { six months. }\end{array}$ & \multirow{2}{*}{$\begin{array}{l}\text { Dermatobia hominis } \\
\downarrow \text { number of parasites } \\
\text { equivalent or in } \\
\text { comparison to the to the } \\
\text { conventional treatment. } \\
\text { Boophilus microplus } \\
\downarrow \text { number of parasites } \\
\text { More effective than the } \\
\text { conventional treatment. }\end{array}$} & \multirow[t]{2}{*}{$\begin{array}{l}\text { Deffune and Oliveira, } \\
2011\end{array}$} \\
\hline $\begin{array}{l}\text { Dermatobia } \\
\text { hominis }\end{array}$ & $\begin{array}{l}\text { Biotherapic } 12 \mathrm{CH} \\
\left(10^{-12}\right)\end{array}$ & & $\begin{array}{l}\text { Biotherapic } 12 \mathrm{CH} 2 \mathrm{~mL} / \text { mixed with } \\
\text { the mineral salt/ after the use of } \\
\text { Biotherapic } 12 \mathrm{DH} \text { for } 6 \text { months. }\end{array}$ & & \\
\hline $\begin{array}{l}\text { Rhipicephalus } \\
\text { (Boophilus) } \\
\text { microplus }\end{array}$ & $\begin{array}{l}\text { Factor C\&MC*} \\
\text { Biotherapic } \\
12 \mathrm{CH}\left(10^{-24}\right)\end{array}$ & $\begin{array}{l}\text { bovine } \\
\text { (180-240 days old) }\end{array}$ & $20 \mathrm{~g} /$ day / pre infection. & $\downarrow$ number of parasites & $\begin{array}{l}\text { Costa Júnior and } \\
\text { Furlong, } 2011\end{array}$ \\
\hline
\end{tabular}

Table 1 lists articles [17-23] involving the use of homeopathic medication for treatment of arthropod infestations. In the treatment of cattle infestations by Rhipicephalus (Boophilus) microplus, use of biotherapic medications has shown interesting results, such as reduction of the parasites' size and interruption of their biological cycle, with consequent reduction also of parasites' number[17-23], sometimes even exceeding the effects observed with conventional treatment.

Biotherapic treatment of cattle infested with Dermatobia hominis also also exhibited satisfactory results, including reduction of the parasites' number and of the size of lesions. Those findings are suggestive of balance in the parasite-host relationship during the period of infestation [18,22].

Those studies showed that neither the medicine dose, nor the animals' age seem to influence the results, thus agreeing with the authors who observed that although the frequency of administration is a relevant factor, the actual dose used is not [24.25].Those animals received the medication mixed in the food, ad libitum, which indicates that continuous stimulation seems to afford satisfactory outcomes.

Aleixo et al.[26-29] found similar the same results in experimental studies conducted with mice infected by Trypanosoma cruzi in the acute phase. The groups subjected to continuous treatment with a biotherapic agent over a long period of time exhibited better response compared to the ones subjected to shorter treatment or with a single daily dose. Once again, the relevance of the stimulus frequency is highlighted. 
Table 2: Utilization of homeopathic medications in helminthiasis.

\begin{tabular}{|c|c|c|c|c|c|}
\hline PARASITE & $\begin{array}{l}\text { MEDICATION* } \\
\text { (POTENCY) }\end{array}$ & $\begin{array}{c}\text { ANIMAL MODEL } \\
\text { (AGE) }\end{array}$ & TREATMENT REGIMENS & EFFECT & REFERENCE \\
\hline Oesophagostomum sp & $\begin{array}{l}\text { Phosphorus } \\
6 \mathrm{CH}\left(10^{-12}\right)\end{array}$ & $\begin{array}{l}\text { bovine } \\
\text { (120-210 days) }\end{array}$ & $\begin{array}{l}\text { Mixed with the mineral salt ( } a d \\
\text { libitum) for } 30 \text { days. }\end{array}$ & $\begin{array}{l}\downarrow \text { number of } \\
\text { parasites } \\
\text { Clinical improvement }\end{array}$ & $\begin{array}{l}\text { Almeida and Pinto, } \\
2002\end{array}$ \\
\hline Trichinella spirallis & $\begin{array}{l}\text { Podophyllum TM } \\
\text { Cina } \\
30 \mathrm{CH}\left(10^{-60}\right) \\
\text { Santonin } \\
30 \mathrm{CH}\left(10^{-60}\right)\end{array}$ & $\begin{array}{l}\text { murine } \\
\text { (age not provided) }\end{array}$ & $\begin{array}{l}60 \mathrm{mg} / \mathrm{kg} / \text { day } / \text { animal } / \mathrm{V} . \mathrm{O} \\
\text { from the } 7 \text { th day of infection } \\
\text { for } 120 \text { days. }\end{array}$ & $\downarrow$ number of larvae & Sukul et al.,2005 \\
\hline $\begin{array}{l}\text { Oesophagostomum } s p \\
\text { Haemonchus contortus } \\
\text { Trichostrongylus sp } \\
\text { Cooperia spp }\end{array}$ & $\begin{array}{l}\text { Complex: } \\
\text { Factor VERM } \\
\text { (formule not presented) }\end{array}$ & ovine (540 days) & $\begin{array}{l}\text { Mixed with the mineral salt, } \\
1,6 \mathrm{~g} / \text { day/ animal, ad libitum. }\end{array}$ & $\begin{array}{l}\text { No } \downarrow \text { eggs } / g \text { of feces } \\
\text { Not clinically } \\
\text { evaluated }\end{array}$ & Rocha et al.,2006 \\
\hline Nematodes & $\begin{array}{l}\text { Complex: } \\
\text { Sulphur } \\
\text { 30DH }\left(10^{-30}\right) \\
\text { Ferrum phosphoricum } \\
6 \mathrm{DH}\left(10^{-6}\right) \\
\text { Arsenicum álbum } \\
6 \mathrm{DH}\left(10^{-6}\right) \\
\text { Mercurus solubilis } \\
6 \mathrm{DH}\left(10^{-6}\right) \\
\end{array}$ & $\begin{array}{l}\text { ovine }(150 \\
\text { days })\end{array}$ & $\begin{array}{l}10 \text { drops } 2 \text { times a day/ diluted } \\
\text { in water administered ad } \\
\text { libitum. }\end{array}$ & $\begin{array}{l}\text { No } \downarrow \text { eggs/g of feces } \\
\downarrow \text { symptoms of } \\
\text { intestinal parasitoses }\end{array}$ & Cavalcanti et al.,2007 \\
\hline Giardia muris & $\begin{array}{l}\text { Allium sativum } \\
\text { Arsenicum album } \\
\text { Carduus marianus } \\
\text { (potency not presented) }\end{array}$ & murine (28 days) & $\begin{array}{l}100 \text { drops/L diluted in water } \\
\text { administered ad libitum for } 50 \\
\text { days. }\end{array}$ & $\begin{array}{l}\downarrow \text { number of } \\
\text { parasites } \\
\downarrow \text { eggs/g of feces }\end{array}$ & Silva et al.,2007a \\
\hline \multirow[t]{3}{*}{ Haemonchus contortus } & $\begin{array}{l}\text { Ferrum phosphoricum } \\
6 \mathrm{DH}\left(10^{-6}\right)\end{array}$ & $\begin{array}{l}\text { ovine } \\
\text { (135 days) }\end{array}$ & $\begin{array}{l}\text { Administered in alternate days } \\
\text { for } 10 \text { days. }\end{array}$ & \multirow{3}{*}{$\begin{array}{l}\downarrow \text { number of larvae } \\
\text { Improvement of the } \\
\text { biochemical aspects } \\
\text { Improvement of the } \\
\text { immunological } \\
\text { aspects }\end{array}$} & \multirow[t]{3}{*}{ Zacharias et al., 2008} \\
\hline & $\begin{array}{l}\text { Arsenicum álbum } \\
6 \mathrm{DH}\left(10^{-6}\right)\end{array}$ & & $\begin{array}{l}\text { Administered in alternate days } \\
\text { for } 10 \text { days. }\end{array}$ & & \\
\hline & $\begin{array}{l}\text { Calcarea carbonica } \\
12 \mathrm{DH}\left(10^{-12}\right)\end{array}$ & & $\begin{array}{l}\text { Admionistered after } 10 \text { days } \\
\text { from the beginning of the } \\
\text { treatment, for } 10 \text { days ( } 2 x / \text { day) }\end{array}$ & & \\
\hline $\begin{array}{l}\text { Oesophagostomumsp } \\
\text { Haemonchus contortus } \\
\text { Trichostrongylus } s p\end{array}$ & $\begin{array}{l}\text { Complex: } \\
\text { Factor VERM } \\
\text { (formule not presented) }\end{array}$ & caprine (365 days) & $\begin{array}{l}\text { Mixed with the mineral salt, } \\
1,6 \mathrm{~g} / \text { day /animal, ad libitum, } \\
\text { for } 18 \text { months. }\end{array}$ & $\begin{array}{l}\text { No } \downarrow \text { eggs } / g \text { of feces } \\
\text { Not clinically } \\
\text { evaluated }\end{array}$ & Chagas et al.,2008 \\
\hline Nematodes & $\begin{array}{l}\text { Complex: } \\
\text { VERM } 100 \\
\text { (formule not presented) }\end{array}$ & $\begin{array}{l}\text { ovine } \\
\text { (180-1080 days) }\end{array}$ & $\begin{array}{l}\text { Mixed with the mineral salt } \\
10 \mathrm{~g} / \text { animal/ day, administered } \\
\text { ad libitum. }\end{array}$ & $\begin{array}{l}\text { No } \downarrow \text { eggs/g of feces } \\
\downarrow \text { symptoms of } \\
\text { intestinal parasitoses }\end{array}$ & Andrade et al.,2011 \\
\hline
\end{tabular}

Table 2 lists articles [3,5,21,23,30-35] involving the use of homeopathic medication for treatment of helminthic infections [5,30-33]. The table also lists experimental studies [19,32].

In this case, the classical homeopathic medicines are chosen based on the so-called "epidemic genus", which consists in the identification of the set of symptoms common to a group of ill animals, which is used to select the appropriate medicines based on the principle of therapeutic similarity. These cases showed interesting results, as the parasite load remained steady, while the symptoms showed remission, leading to the hypothesis of "return to homeostasis," in which balance is established in the parasite-host relationship [5,19,30-34].

Also in those studies, application of constant stimulus, which was achieved by mixing the medication mixed to the food, seemed to be more significant than the medication dose. As Table 2 shows, that pattern was detected also when biotherapic medications were used.

Studies conducted with protozoan parasites and well-known experimental models provided relevant clues for the understanding of the mechanism of action of homeopathic medicines. Table 3 summarizes the results of experiments involving infection by protozoan parasites. 
In one experimental study, a group of mice was treated with biotherapic of Toxoplasma gondii in high dilution before induction of infection. The progression of infection exhibited a pattern different, and the clinical condition of that group was better, with fewer eye lesions, in that group compared to the controls [36].

In human beings, cases of ocular toxoplasmosis treated with homeopathic medications selected based on repertory analysis of symptoms showed satisfactory outcomes, with improvement of the visual acuity and of the general state of patients[37]. In mice and rats naturally infected with coccidian parasites[35], the use of a homeopathic complex consisting of Allium sativum, Carduus marianus and Arsenicum album eliminated the infection in the mice and decreased the number of cysts eliminated by the rats. It is worth to observe that the authors did not report the potency used.

Studies using a model of experimental infection of mice by Trypanosoma cruzi found that highly diluted medications affected the host's immune balance. Variables such as frequency of administration, medication potency, medication selection and their combinations are of great relevance.

The variables studied are many: parasitemia, mortality, survival time and blood and immune parameters [26,38-41].One study reported increase of the apoptosis index and decrease of the TGF- $B$ concentration in the serum of the group of animals treated with a biotherapic medication, compared to the control group [40].

The conclusions of studies that employed models under carefully controlled experimental conditions exhibited the same pattern as the one found in the treatment of farm animals, which showed promising clinical results, where, even when the experimental conditions were not fully controlles.. In both cases, animals subjected to long and continuous treatment exhibited better outcomes compared to the ones treated for shorter periods of time or received one single daily dose. 
Table 3: The utilization of homeopathic medications in protozoosis.

\begin{tabular}{|c|c|c|c|c|c|}
\hline PARASITE & $\begin{array}{l}\text { MEDICATION* } \\
\text { (POTENCY) }\end{array}$ & $\begin{array}{l}\text { ANIMAL } \\
\text { MODEL (AGE) }\end{array}$ & TREATMENT REGIMENS & EFFECT & REFERENCE \\
\hline $\begin{array}{l}\text { Leishmania } \\
\text { amazonensis }\end{array}$ & $\begin{array}{l}\text { Complex: } \\
\text { Canova* }\end{array}$ & $\begin{array}{l}\text { murine } \\
\text { (28 days) } \\
\text { in vitro }\end{array}$ & $\begin{array}{l}0.2 \mathrm{~mL} / \text { gavage } \\
\text { Subcutaneous } \\
\text { administration for } 9 \text { days. }\end{array}$ & $\begin{array}{l}\downarrow \text { macrophages infection } \\
\text { index. } \\
\uparrow N O\end{array}$ & $\begin{array}{l}\text { Pereira et } \\
\text { al.,2005 }\end{array}$ \\
\hline \multirow[t]{2}{*}{ Trypanosoma cruzi } & \multirow[t]{2}{*}{$\begin{array}{l}\text { Biotherapic } \\
30 \mathrm{DH}\left(10^{-30}\right)\end{array}$} & \multirow[t]{2}{*}{$\begin{array}{l}\text { murine } \\
\text { (28 days) }\end{array}$} & $\begin{array}{l}\text { Treated } 8 \text { days before the } \\
\text { infection for } 7 \text { days, } 50 \\
\text { uL/day. }\end{array}$ & \multirow[t]{2}{*}{$\begin{array}{l}\uparrow \text { survival rate } \\
\uparrow \lg G\end{array}$} & \multirow[t]{2}{*}{$\begin{array}{l}\text { Queiroz et } \\
\text { al.,2006 }\end{array}$} \\
\hline & & & $\begin{array}{l}\text { Treated after the infection } \\
50 \text { uL/day for } 7 \text { days. }\end{array}$ & & \\
\hline $\begin{array}{l}\text { Plasmodium } \\
\text { berghei }\end{array}$ & $\begin{array}{l}\text { Eupatorium } \\
\text { perfolatum } \\
30 \mathrm{CH}\left(10^{-60}\right) \\
\text { Arsenicum album } \\
0 / 6\end{array}$ & $\begin{array}{l}\text { murine } \\
\text { (42-56 days) }\end{array}$ & $\begin{array}{l}8 \mu \mathrm{L} / 200 \mu \mathrm{L} / \text { every } 24 \\
\text { hours for } 9 \text { days through } \\
\text { gavage }\end{array}$ & $\begin{array}{l}\downarrow \text { schizogony } \\
\downarrow \text { número de schizonts }\end{array}$ & $\begin{array}{l}\text { Lira-Salazar et } \\
\text { al.,2006 }\end{array}$ \\
\hline Babesia gibsoni & $\begin{array}{l}\text { Crotalus horridus } \\
200 \mathrm{CH} \\
\left(10^{-400}\right)\end{array}$ & $\begin{array}{l}\text { canine } \\
\text { (age not } \\
\text { mentioned) }\end{array}$ & $\begin{array}{l}4 \text { pills/ } 4 x \text { days/ } 14 \text { days/ } \\
\text { V.O. }\end{array}$ & $\begin{array}{l}\downarrow \text { number of parasites } \\
\text { Clinical improvement } \\
\text { Improvement of the } \\
\text { haematological parameters }\end{array}$ & $\begin{array}{l}\text { Chaudhuri and } \\
\text { Varshney, } \\
2007\end{array}$ \\
\hline Trypanosoma cruzi & $\begin{array}{l}\text { Complex: } \\
\text { Canova* }\end{array}$ & $\begin{array}{l}\text { murine } \\
\text { (28 days) }\end{array}$ & $\begin{array}{l}0.2 \mathrm{~mL} / \text { day/ } 20 \text { days/ } \\
\text { gavage }\end{array}$ & $\begin{array}{l}\text { Change in the genetic } \\
\text { profile (RAPD) when used } \\
\text { in association with } \\
\text { Benznidazol }\end{array}$ & $\begin{array}{l}\text { Aleixo et } \\
\text { al.,2008 }\end{array}$ \\
\hline \multirow[t]{2}{*}{ Trypanosoma cruzi } & $\begin{array}{l}\text { Phosphorus 12DH } \\
\left(10^{-12}\right)\end{array}$ & $\begin{array}{l}\text { murine } \\
\text { (adult) }\end{array}$ & $\begin{array}{l}\text { Administered } 3 \text { drops } \\
(0,6 \mathrm{~mL}) / \text { day/ V.O. with a } \\
\text { dropper. } \\
\text { Treated for } 20 \text { days after } \\
\text { the infection. }\end{array}$ & $\begin{array}{l}\uparrow P P \\
\uparrow m a x i m u m \text { peak of } \\
\text { parasites } \\
\uparrow \text { survival rate }\end{array}$ & \multirow[t]{2}{*}{$\begin{array}{l}\text { Almeida et } \\
\text { al.,2008 }\end{array}$} \\
\hline & $\begin{array}{l}\text { Biotherapic } \\
12 \mathrm{DH}\left(10^{-12}\right)\end{array}$ & & $\begin{array}{l}\text { Administered } 3 \text { drops } \\
(0,6 \mathrm{~mL}) / \text { day/ V.O. with a } \\
\text { dropper. } \\
\text { Treated before the infection } \\
\text { for } 20 \text { days, with an interval } \\
\text { of } 10 \text { days. } \\
\text { Treated after the infection } \\
\text { for } 20 \text { days. }\end{array}$ & $\begin{array}{l}\downarrow P P \\
\downarrow \text { maximum peak of } \\
\text { parasites } \\
\downarrow \text { mortality rate. }\end{array}$ & \\
\hline \multirow[t]{3}{*}{ Trypanoso evansi } & \multirow[t]{3}{*}{$\begin{array}{l}\text { Complex: } \\
\text { CH Coxvit* }\end{array}$} & \multirow[t]{3}{*}{$\begin{array}{l}\text { murine } \\
\text { (60 days) }\end{array}$} & $\begin{array}{l}\text { 100drops/ L diluted in } \\
\text { water, } 30 \text { days before } \\
\text { inoculation. }\end{array}$ & $\uparrow$ survival rate & \multirow[t]{3}{*}{$\begin{array}{l}\text { Silva et } \\
\text { al.,2009 }\end{array}$} \\
\hline & & & $\begin{array}{l}\text { 100drops/ L diluted in water } \\
\text { from the inoculation } \\
\text { onwards. }\end{array}$ & $\uparrow$ survival rate & \\
\hline & & & $\begin{array}{l}100 \text { crops/ L diluted in } \\
\text { water } 20 \text { days after the } \\
\text { inoculation. }\end{array}$ & $\begin{array}{l}\text { There wasn't } \uparrow \text { survival rate } \\
\text { nor a difference in the PP }\end{array}$ & \\
\hline \multirow[t]{3}{*}{ Trypanosoma cruzi } & \multirow{3}{*}{$\begin{array}{l}\text { Biotherapic 17DH } \\
\left(10^{-17}\right)\end{array}$} & $\begin{array}{l}\text { murine } \\
\text { (28 days) }\end{array}$ & \multirow{3}{*}{$\begin{array}{l}0,2 \mathrm{~mL} / \text { for } 20 \text { days through } \\
\text { gavage. }\end{array}$} & $\begin{array}{l}\text { parasitaemia and the peak } \\
\text { of parasites similar among } \\
\text { the treated and control }\end{array}$ & $\begin{array}{l}\text { Sandri et } \\
\text { al.,2009 }\end{array}$ \\
\hline & & & & groups & \\
\hline & & $\begin{array}{l}\text { murine } \\
\text { (56 days) }\end{array}$ & & $\begin{array}{l}\uparrow \text { parasitaemia } \\
\uparrow \text { peak of parasites }\end{array}$ & \\
\hline \multirow[t]{3}{*}{ Trypanosoma cruzi } & $\begin{array}{l}\text { Biotherapic } 7 \mathrm{DH}\left(10^{-}\right. \\
7)\end{array}$ & $\begin{array}{l}\text { murine } \\
\text { (28 days) }\end{array}$ & $\begin{array}{l}0,2 \mathrm{~mL} / \text { for } 20 \text { days after } \\
\text { infection/ gavage }\end{array}$ & $\begin{array}{l}\text { Similar parasitaemia among } \\
\text { the treated and control } \\
\text { groups }\end{array}$ & \multirow[t]{3}{*}{$\begin{array}{l}\text { Ferraz et } \\
\text { al.,2009 }\end{array}$} \\
\hline & $\begin{array}{l}\text { Biotherapic 17DH } \\
\left(10^{-17}\right)\end{array}$ & & & $\uparrow$ peak of parasites & \\
\hline & $\begin{array}{l}\text { Biotherapic 12CH } \\
\left(10^{-24}\right)\end{array}$ & & & $\uparrow$ parasitaemia & \\
\hline Trypanosoma cruzi & $\begin{array}{l}\text { Biotherapic 7DH } \\
\left(10^{-7}\right)\end{array}$ & $\begin{array}{l}\text { murine } \\
\text { (28 days) }\end{array}$ & $\begin{array}{l}0,2 \mathrm{~mL} / 30 \text { days pré } \\
\text { infection/ V.O. }\end{array}$ & $\begin{array}{l}\uparrow P P P \\
\uparrow \text { peak of parasites } \\
\uparrow \text { survival rates } \\
\downarrow \text { red blood cell }\end{array}$ & $\begin{array}{l}\text { Billoti et } \\
\text { al.,2009 }\end{array}$ \\
\hline Trypanosoma cruzi & $\begin{array}{l}\text { Biotherapic } \\
17 \mathrm{DH}\left(10^{-17}\right)\end{array}$ & $\begin{array}{l}\text { murine } \\
\text { (28 days) }\end{array}$ & $\begin{array}{l}0.2 \mathrm{~mL} / \text { animal/gava-ge from } \\
\text { the } 4 \text { th day of infection } \\
\text { onwards. }\end{array}$ & $\begin{array}{l}\uparrow \text { tissue parasitism and } \\
\text { areas of inflammation in the } \\
\text { liver similar to the control } \\
\text { group. }\end{array}$ & $\begin{array}{l}\text { Sandri et } \\
\text { al.,2010 }\end{array}$ \\
\hline
\end{tabular}




\begin{tabular}{|c|c|c|c|c|c|}
\hline & & $\begin{array}{l}\text { murine } \\
\text { (56 days) }\end{array}$ & & $\begin{array}{l}\downarrow \text { tissue parasitism and } \\
\text { areas of inflammation in the } \\
\text { liver. }\end{array}$ & \\
\hline \multirow[t]{3}{*}{ Trypanosoma cruzi } & $\begin{array}{l}\text { Biotherapic } \\
7 \mathrm{DH}\left(10^{-7}\right)\end{array}$ & $\begin{array}{l}\text { murine } \\
\text { (28 days) }\end{array}$ & $\begin{array}{l}\text { Treatment } 3 \text { days before } \\
\text { and } 3 \text { days after the } \\
\text { infection: } 10 \mu \mathrm{L} / \mathrm{mL} \\
\text { administered in water ad } \\
\text { libitum. }\end{array}$ & \multirow[t]{3}{*}{$\begin{array}{l}\text { Better performance of the } \\
\text { treatment administered } \\
\text { before and after infection } \\
\text { with: } \\
\downarrow \text { parasitaemia } \\
\downarrow P P \\
\uparrow \text { survival rate }\end{array}$} & \multirow[t]{3}{*}{$\begin{array}{l}\text { Ferraz et } \\
\text { al.,2010 }\end{array}$} \\
\hline & & & $\begin{array}{l}\text { Treatment } 3 \text { days before } \\
\text { the infection: } 10 \mu \mathrm{L} / \mathrm{mL} \\
\text { administered in water ad } \\
\text { libitum. }\end{array}$ & & \\
\hline & & & $\begin{array}{l}\text { Treatment } 3 \text { days before } \\
\text { and after the infection for a } \\
\text { long period: } 10 \mu \mathrm{L} / \mathrm{mL} \\
\text { administered in water ad } \\
\text { libitum }\end{array}$ & & \\
\hline Trypanosoma cruzi & $\begin{array}{l}\text { Complex: } \\
\text { Canova* }\end{array}$ & $\begin{array}{l}\text { murine } \\
\text { (28 days) }\end{array}$ & $\begin{array}{l}0.2 \mathrm{~mL} / \text { animal } / \text { day/ } \\
\text { gavage } / 20 \text { days. }\end{array}$ & $\begin{array}{l}\text { Early mortality } \\
\uparrow \text { peak of parasites } \\
\text { Change in the tissue } \\
\text { tropism. }\end{array}$ & $\begin{array}{l}\text { Pupulim et } \\
\text { al.,2010 }\end{array}$ \\
\hline Toxoplasma gondii & $\begin{array}{l}\text { Biotherapic } \\
7 \mathrm{DH}\left(10^{-7}\right)\end{array}$ & $\begin{array}{l}\text { murine } \\
\text { (57-59 days) }\end{array}$ & $\begin{array}{l}\text { Treatment pré infection: } \\
0,1 \mathrm{~mL} / 4 \mathrm{x} \text { day, after } 2 \mathrm{x} / \text { day/ } \\
3 \text { days. }\end{array}$ & $\begin{array}{l}\uparrow \text { number of brain cysts } \\
\uparrow \text { ocular alterations } \\
\downarrow \text { ocular pressure }\end{array}$ & $\begin{array}{l}\text { Braga et } \\
\text { al.,2011b }\end{array}$ \\
\hline \multirow[t]{3}{*}{ Trypanosoma cruzi } & $\begin{array}{l}\text { Biotherapic } \\
7 \mathrm{DH}\left(10^{-7}\right)\end{array}$ & $\begin{array}{l}\text { murine } \\
\text { (28 days) }\end{array}$ & $\begin{array}{l}10 \mu \mathrm{L} / \mathrm{mL} \text { administered in } \\
\text { water ad libitum for } 20 \text { days } \\
\text { after infection. }\end{array}$ & \multirow{3}{*}{$\begin{array}{l}\downarrow \text { the area under the } \\
\text { parasitemia curve, } \\
\downarrow \text { parasitemia peak and } \\
\downarrow \text { total parasitaemia of the } \\
\text { infected mice without } \downarrow \\
\text { mortality rate or } \uparrow \text { survival } \\
\text { period. Only for the group } \\
\text { treated } 7 \text { days before the } \\
\text { infection. }\end{array}$} & \multirow[t]{3}{*}{$\begin{array}{l}\text { Ferraz et } \\
\text { al.,2011a }\end{array}$} \\
\hline & & & $\begin{array}{l}10 \mu \mathrm{L} / \mathrm{mL} \text { administered in } \\
\text { water ad libitum for } 7 \text { days } \\
\text { before the infection. }\end{array}$ & & \\
\hline & & & $\begin{array}{l}10 \mu \mathrm{L} / \mathrm{mL} \text { administered in } \\
\text { water ad libitum for } 30 \\
\text { days before the infection. }\end{array}$ & & \\
\hline \multirow[t]{7}{*}{ Trypanosoma cruzi } & $\begin{array}{l}\text { Biotherapic } \\
15 \mathrm{DH}\left(10^{-15}\right)\end{array}$ & $\begin{array}{l}\text { murine } \\
\text { (28 days) }\end{array}$ & \multirow{7}{*}{$\begin{array}{l}\text { Treatment } 3 \text { days before } \\
\text { and } 3 \text { days after the } \\
\text { infection: } 10 \mu \mathrm{L} / \mathrm{mL} \\
\text { administered inwater ad } \\
\text { libitum. For all groups. }\end{array}$} & $\begin{array}{l}\downarrow \text { parasitaemia } \\
\downarrow \mathrm{PP}\end{array}$ & \multirow[t]{7}{*}{$\begin{array}{l}\text { Ferraz et al., } \\
2011 \mathrm{~b}\end{array}$} \\
\hline & & & & $\downarrow$ mortality rate & \\
\hline & $\begin{array}{l}\text { Biotherapic } \\
16 \mathrm{DH}\left(10^{-32}\right)\end{array}$ & & & $\begin{array}{l}\downarrow \text { parasitaemia } \\
\downarrow P P\end{array}$ & \\
\hline & & & & $\downarrow$ mortality rate & \\
\hline & $\begin{array}{l}\text { Biotherapic } \\
17 \mathrm{DH}\left(10^{-34}\right)\end{array}$ & & & $\begin{array}{l}\downarrow \text { parasitaemia } \\
\downarrow P P\end{array}$ & \\
\hline & & & & $\downarrow$ mortality rate & \\
\hline & $\begin{array}{l}\text { Biotherapic Chord: } \\
\text { 15DH }\left(10^{-15}\right), 16 \mathrm{DH} \\
\left(10^{-16}\right) \text { e } 17 \mathrm{DH}\left(10^{-}\right. \\
17)\end{array}$ & & & $\begin{array}{l}\uparrow \text { parasitaemia } \\
\downarrow P P \\
\downarrow \text { mortality rate }\end{array}$ & \\
\hline \multirow[t]{2}{*}{ Trypanosoma cruzi } & $\begin{array}{l}\text { Biotherapic } \\
17 \mathrm{DH}\left(10^{-17}\right)\end{array}$ & $\begin{array}{l}\text { murine } \\
\text { (28 days) }\end{array}$ & $\begin{array}{l}0.2 \mathrm{~mL} / \text { animal/gava-ge D.U. } \\
\text { for } 3 \text { days. }\end{array}$ & \multirow[t]{2}{*}{$\begin{array}{l}\downarrow \text { mortality rate } \\
\text { Clinical improvement in the } \\
\text { animals treated for longer } \\
\text { periods. }\end{array}$} & \multirow[t]{2}{*}{$\begin{array}{l}\text { Aleixo et } \\
\text { al.,2011a }\end{array}$} \\
\hline & & & $\begin{array}{l}10 \mu \mathrm{L} / \mathrm{mL} \text { administered in } \\
\text { water ad libitum for } 20 \text { days } \\
\text {. }\end{array}$ & & \\
\hline \multirow[t]{3}{*}{ Trypanosoma cruzi } & $\begin{array}{l}\text { Biotherapic } \\
\text { 200DH } \\
\left(10^{-200}\right)\end{array}$ & $\begin{array}{l}\text { murine } \\
\text { (28 days) }\end{array}$ & \multirow{3}{*}{$\begin{array}{l}\text { For all groups: } \\
10 \mu \mathrm{L} / \mathrm{mL} \text { administered in } \\
\text { water ad libitum for } 24 \\
\text { hours } \\
1 \mu \mathrm{L} / \mathrm{mL} \text { administered in } \\
\text { water ad libitum for long } \\
\text { periods }\end{array}$} & \multirow{3}{*}{$\begin{array}{l}\downarrow \text { age } \uparrow \text { parasitaemia } \\
\text { (the older has the higher } \\
\text { parasitaemia level) } \\
\uparrow \text { period of treatment } \\
\downarrow \text { parasitaemia. (the longer } \\
\text { the period of treatment, the } \\
\text { lower the parasitaemia } \\
\text { level) }\end{array}$} & \multirow[t]{3}{*}{$\begin{array}{l}\text { Aleixo et } \\
\text { al.,2011c }\end{array}$} \\
\hline & & $\begin{array}{l}\text { murine } \\
\text { (38 days) }\end{array}$ & & & \\
\hline & & $\begin{array}{l}\text { murine } \\
\text { (56 days) }\end{array}$ & & & \\
\hline Trypanosoma cruzi & $\begin{array}{l}\text { Biotherapic } \\
17 \mathrm{DH}\left(10^{-17}\right)\end{array}$ & $\begin{array}{l}\text { murine } \\
\text { (28 days) }\end{array}$ & $\begin{array}{l}0.2 \mathrm{~mL} / \text { animal/gava-ge/ } 3 \\
\text { days from the } 4 \text { th day of } \\
\text { infection onwards. }\end{array}$ & †apoptosis liver cells. & $\begin{array}{l}\text { Sandri et } \\
\text { al.,2011a }\end{array}$ \\
\hline
\end{tabular}




\begin{tabular}{|c|c|c|c|c|c|}
\hline \multirow[t]{2}{*}{ Trypanosoma cruzi } & \multirow{2}{*}{$\begin{array}{l}\text { Biotherapic } \\
17 \mathrm{DH}\left(10^{-17}\right)\end{array}$} & \multirow{2}{*}{$\begin{array}{l}\text { murine } \\
\text { (28 days) }\end{array}$} & \multicolumn{2}{|l|}{ 0.2mL/animal/gava-ge D.U. } & \multirow{2}{*}{$\begin{array}{l}\text { Sandri et } \\
\text { al.,2011b }\end{array}$} \\
\hline & & & $\begin{array}{l}10 \mu \mathrm{L} / \mathrm{mL} \text { administered in } \\
\text { water ad libitum }\end{array}$ & $\begin{array}{l}\downarrow \text { parasitaemia } \\
\downarrow \text { mortality rate }\end{array}$ & \\
\hline Toxoplasma gondii & $\begin{array}{l}\text { Biotherapic } \\
\text { 200DH } \\
\left(10^{-200}\right)\end{array}$ & $\begin{array}{l}\text { murine } \\
\text { (56 days) }\end{array}$ & $\begin{array}{l}0.1 \mathrm{~mL} / \text { animal } / \mathrm{D} . \mathrm{U} \\
\text { day/gavage for } 3 \text { days after } \\
\text { the infection. }\end{array}$ & $\downarrow$ tissue parasitism. & $\begin{array}{l}\text { Braga et } \\
\text { al.,2011a }\end{array}$ \\
\hline Toxoplasma gondii & $\begin{array}{l}\text { Biotherapic } \\
200 \mathrm{DH} \\
\left(10^{-200}\right)\end{array}$ & $\begin{array}{l}\text { murine } \\
\text { (56 days) }\end{array}$ & $\begin{array}{l}0.1 \mathrm{~mL} / \text { animal/ } \mathrm{D} . \mathrm{U} \\
\text { day/gavage for } 3 \text { days after } \\
\text { the infection }\end{array}$ & $\downarrow$ brain parasitism & $\begin{array}{l}\text { Ferreira et } \\
\text { al.,2011 }\end{array}$ \\
\hline
\end{tabular}

Canova ${ }^{*}$ : Thuya occidentalis 19DH Bryonia alba 18DH, Aconitum napellus 11DH, Arsenicum album 19DH, Lachesis muta 18DH.

CH Coxvit $\AA^{*}$ :Allium sativum, Carduus marianus, Arsenicum album. (dynamizations not presented)

\section{Table 4: Summary of characteristics of articles reviewed.}

COMMENTS

\begin{tabular}{|c|c|c|c|}
\hline $\begin{array}{l}\text { There is no information } \\
\text { about experiment } \\
\text { repetitions. } \\
\text { No replication }\end{array}$ & $\begin{array}{l}\text { Almeida \& Pinto, 2002; } \\
\text { Arenales \& Coelho, 2002; } \\
\text { Sukul et al., 2005; } \\
\text { Rocha et al., 2005; } \\
\text { Pereira et al., 2005; } \\
\text { Lira-Salazar 2006; } \\
\text { Fonseca \& Goloubeff, 2006; } \\
\text { Queiroz et al., 2006; } \\
\text { Cavalcanti et al.,2007; } \\
\text { Silva et al.,2007a } \\
\text { Chaudhuri \& Varshney, 2007; } \\
\text { Chagas et al., 2008; }\end{array}$ & $\begin{array}{l}\text { Silva et al., 2008; } \\
\text { Zacharias et al., 2008; } \\
\text { Aleixo et al., 2008; } \\
\text { Almeida et al., 2008; } \\
\text { Billotti et al., 2009; } \\
\text { Ferraz et al., 2009; } \\
\text { Silva et al., 2009; } \\
\text { Sandri et al.,2009; } \\
\text { Signoretti et al., 2010; } \\
\text { Pupulin et al.,2010; } \\
\text { Gazim et al., 2010; } \\
\text { Ferraz et al., 2010; } \\
\text { Sandri et al.,2010; } \\
\text { Aleixo et al.,2011a; }\end{array}$ & $\begin{array}{l}\text { Aleixo et al.,2011c; } \\
\text { Braga et al.,2011a; } \\
\text { Braga et al.,2011b; } \\
\text { Andrade et al., 2011; } \\
\text { Ferraz et al.,2011a; } \\
\text { Ferraz et al.,2011b; } \\
\text { Sandri et al.,2011a; } \\
\text { Sandri et al.,2011b; } \\
\text { Ferreira et al.,2011; } \\
\text { Costa-Júnior \&; Furlong, 2011; } \\
\text { Deffune \& Oliveira, 2011. }\end{array}$ \\
\hline $\begin{array}{l}\text { The articles do not } \\
\text { accurately inform the type of } \\
\text { tests (blinding, } \\
\text { randomisation, blocking, } \\
\text { stratification) }\end{array}$ & $\begin{array}{l}\text { Almeida \& Pinto, 2002; } \\
\text { Arenales \& Coelho, 2002; } \\
\text { Sukul et al., 2005; } \\
\text { Rocha et al., 2005; } \\
\text { Pereira et al., 2005; } \\
\text { Lira-Salazar 2006; } \\
\text { Fonseca \& Goloubeff, 2006; } \\
\text { Queiroz et al., 2006; }\end{array}$ & $\begin{array}{l}\text { Chaudhuri \& Varshney, 2007; } \\
\text { Chagas et al., 2008; } \\
\text { Zacharias et al., 2008; } \\
\text { Aleixo et al., 2008; } \\
\text { Almeida et al., 2008; } \\
\text { Silva et al., 2008; } \\
\text { Ferraz et al., 2009; } \\
\text { Silva et al., 2009; }\end{array}$ & $\begin{array}{l}\text { Signoretti et al., 2010; } \\
\text { Pupulin et al.,2010; } \\
\text { Gazim et al., 2010; } \\
\text { Andrade et al., 2011; } \\
\text { Costa-Júnior \&; Furlong, 2011; } \\
\text { Deffune \& Oliveira, 2011. }\end{array}$ \\
\hline $\begin{array}{l}\text { There is no explanation } \\
\text { about the treatment, nor the } \\
\text { medication components, or } \\
\text { the potencies used, } \\
\text { including commercial } \\
\text { formulae. }\end{array}$ & $\begin{array}{l}\text { Almeida \& Pinto, 2002; } \\
\text { Arenales \& Coelho, 2002; } \\
\text { Sukul et al., 2005; } \\
\text { Rocha et al., 2005; } \\
\text { Chaudhuri \& Varshney, 2007; }\end{array}$ & $\begin{array}{l}\text { Chagas et al., 2008; } \\
\text { Silva et al., 2009; } \\
\text { Signoretti et al., 2010; } \\
\text { Andrade et al., 2011; } \\
\text { Costa-Júnior \&; Furlong, 2011; } \\
\text { Deffune \& Oliveira, 2011. }\end{array}$ & \\
\hline $\begin{array}{l}\text { No information about } \\
\text { statisticl analysis. }\end{array}$ & $\begin{array}{l}\text { Almeida \& Pinto, 2002; } \\
\text { Deffune \& Oliveira, } 2011 .\end{array}$ & & \\
\hline Unclear methodology & $\begin{array}{l}\text { Almeida \& Pinto, 2002; } \\
\text { Deffune \& Oliveira, } 2011 .\end{array}$ & & \\
\hline
\end{tabular}

REHBaR Reporting experiments in homeopathic basic research

(Stock-Schroer et al., 2009).

\section{ARTICLES}

Zacharias et al.. 2008;

Ferraz et al., 2009;

Silva et al., 2009;

Sandri et al.,2009;

Signoretti et al., 2010

Gazim et al., 2010

Ferraz et al., 2010;

Chaudhuri \& Varshney, 2007

Ct al., 2008;

Aleixo et al., 2008;

(1) et al., 2008;

et al, 2008;

Ferraz et al., 2009;

Chagas et al., 2008;

Silva et al., 2009;

Costa-Júnior \&; Furlong, 2011;

Deffune \& Oliveira, 2011

\section{Publications and experimental design}

Accurate description of the methods applied in studies that involve the use of highly diluted medications is relevant for the credibility of homeopathy, reproducibility of results and understanding of the mechanism of action of such agents. Factors such as lack of a blind design and appropriate statistical analysis may compromise the credibility of these studies. Also the use of inappropriate control groups may put results into 
question [42]. Several authors [12,42,43] reported problems in published studies using highly diluted medications. While the reproducibility of experiments is an essential criterion in modern research,, it poses a major challenge tofundamental research using highly diluted medications [43]. Authors are required to describe techniques, methods and evaluation of data as completely and with as much detail as possible for readers to be able understand and reproduce the experiments [12].

A number of criteria were formulated for reporting fundamental research on homeopathy [12] to help in the planning of experiments and presentation of results, particularly emphasizing the need for methodological rigor in the analysis of data using statistical methods.

Table 4 presents the characteristics of the articles [12,27,29,38-41,45-57] reviewed here. As it might be seen, their methods did not meet the requirements listed in REHBaR[13]. Several authors conducted clinical trials using commercial formulas, which do not always describe their composition and/or dynamization, making difficult for other researchers to reproduce the experiment. The use of commercial formulas in clinical research is extremely valuable provided that the authors meeta minimum of the criteria required for the description of methods. In the sample analyzed here, personal communications indicated that the experiments had been repeated at least twice, whereas this information had not bneen mentioned in the methods section. This is an example of the features that should be improved[40].

The effect of homeopathic medications is still controversial, and thus the experimental parameters selected for evaluation must be carefully chosen to avoid the analyses of results, considering the animal as a whole.

Precise and thorough descriptions of methods allow different investigators to reproduce experiments, thus contributing to the debate on the effects of highly diluted medications.

Advances in methods and their description are natural occurrences and demand researchers to adapt to them. A clear example of this trend is provided by the papers published in a special issue of journal Homeopathic Research, published by François Lamasson Institute of Homeopathy (IHFL)[58], which was devoted to studies on infection by Trypanosoma cruzi (1994). Although the content of the papers include interesting data, they cannot be accepted as sound based on the current scientific standards as a function of the methods used and how they were described.

Although in recent years research on homeopathy has clearly advanced, both in the implementation of more consistent methods and in the description of data and methods, further improvement is still required. The acknowledgment of homeopathy depends on the credibility of investigators, which is achieved when standard methods are used, and their description, as well as of the results is performed with a minimum standard of accuracy and clarity, which were illustrated by the references mentioned[TT1] in this study [43].

\section{Conclusion}

Many benefits of the use of highly diluted medicines in the treatment of infectious diseases were found in the 39 papers published since 2000 that were located in databases PubMed and SciELOor specialized journals,. In experimental models or in actual treatment of animals, the homeopathic medications exhibited promising clinical outcomes. In both cases, the treated animals consistently showed better results when the medication was administered over a long period of time compared to shorter regimens. Several clinical studies used commercial formulas, which make the reproduction of the experiments difficult. The vast majority of the analyzed articles did not apply the criteria for reportingfundamental research in homeopathy. In parasitic infections, the effect of homeopathic medicines is still controversial, and experimental evaluation parameters should be carefully selected to avoid isolated analysis results[TT2]. Researchers should consider the results in relation to the health of the animals as a whole. 


\section{References}

[1] Farmacopéia Homeopática Brasileira, Brasil - Agência Nacional de Vigilância Sanitária (ANVISA), $3^{\mathrm{a}}$ ed. 2011.

[2] Hahnemann, S. Doenças crônicas. São Paulo: GEHSP "Benoit Mure” 1835, 202p.

[3] Godoi F, Hastenplug M, Balbé TAF, Estivalet-Júnior CNO, Gouvea A: Manejo sanitário do rebanho leiteiro na região sudeste do Paraná. Syn scyUTFPR 2006, 01(1): 1-778.

[4] Almeida LR, Silva FS, Fonseca AH, Soares JPG, Lucke I: Tratamento homeopático da infestação por Dermatobia hominis (Linnaeus Jr, 1781) (Diptera: Cuterebridae) em bovinos sob manejo orgânico. Comunicado Técnico EMBRAPA, Seropêdica, RJ; 2007.

[5] Cavalcanti ASR, ALMEIDA MAO, DIAS AVS: Efeito de medicamentos homepáticos no número de ovos de nematódeos nas fezes (OPG) e no gado de peso em ovinos. Rev Bras Saúde Prod Anim 2007, 8(3):162 -169.

[6] Jacobs J, Fernandez EA, Merizalde B, Avila-Moraes GA, Crothers D: The use of Homeopathy. Homeopathy2007, 96:22-26.

[7] Bracho G, Varela E, Fernandez R, Ordaz B, Marzoa N, Menendez J, Garcia L, Gilling E, Leyva R, Rufen R, Torre R, Solis RL, Batista N, Borrero R, Campa C: Large-scale application of highly-diluted bacteria for Leptospirosis epidemic control. Homeopathy2010, 99:156-166.

[8] World Health Organization (WHO). WHO Traditional Medicine Strategy 2002 - 2005. Available at http://www.who.int

[9] Brasil Ministério da Saúde. Gabinete de ministro. Portaria n971, de 03 de maio de 2006. Diário Oficial da União, Brasília (DF). 2006, 1(84): 20-25.

[10] Ministério da Agricultura, Pecuária e Abastecimento. 1. Saúde animal. 2. Legislação. I. Secretaria de Defesa Agropecuária. II. Departamento de Saúde Animal. III. Título: Programas nacionais de saúde animal do Brasil. INSTRUÇÃO NORMATIVA No 7, de 17 de março de 2004, (ANEXO III), 440p. 2009.

[11] Bonato CM (2009): Homeopatia na Agricultura. In: I Encontro Brasileiro de Homeopatia na Agricultura.Available at http://www.cesaho.com.br/Bibliotecavirtual/arquivos/arquivo_406_cesaho.pdf

[12] Pereira WKV, Lonardoni MVC, Grespan R, Caparroz-Assef SM, Cuman RKN, Bersani-Amado CA: Immunomodulatory effect of Canova medication on experimental Leishmaniaamazonensis infection. J of Infect 2005, 51:157-164.

[13] Stock-Schröer B, Albrecht H, Betti L, Endler PC, Linde K, Lüdtke R, Musial F, Wijk R, Witt C, Baumgartner S: Reporting experiments in homeopathic basic research (REHBaR) - A detailed guideline for authors. Homeopathy 2009, 98:287-298.

[14] Soto FRM, Vuaden ER, Coelho CP, Bonamin LV, Azevedo SS, Benites NR: Efeito da Avena sativa CH6 no metabolismo do sêmen diluído de suínos. Vet e Zootec2009, 16(2): 367-372. 
[15] Soto FRM, Vuaden ER, Coelho CP, Bonamin LV, Azevedo SS, Benites NR, Barros FRO, Goissis MD, Assumpção MEO, Visitin JA, Marques MG: Effects of the utilization of homeopathic elements in comercialdiluente on swine sperm viability. In vitro Cell Dev Biol —Animal 2011, 47:205-209.

[16] Rossi F: Fundamentos da Agrohomeopatia. In: Proceedings of I Encontro Brasileiro de Homeopatia na Agricultura. Campo Grande, Brasil; 2009.

[17] Arenales MC, Coelho EM: Controle complementar de Carrapatos (Boophilus microplus) em Gado Leiteiro (Bostaurus) - Holandês (Puro e Cruzado) com a administração do produto homeopático - FATOR C\&MC, na fazenda da "EPAMIG". Brasil. In: Proceedings of I Conferência Virtual Global sobre Produção Orgânica de Bovinos de Corte. 2002.

[18] Fonseca IG, Goloubeff B: Homeopathic Control of Dermatobiahominis in milk cattle. Int J High Dilution Res 2006, 5(16).

[19] Silva NL, Moletta JL, Minho AP, Filippsen LF: Use of biotherapic in the control of natural infestation by Boophilusmicroplus: pilot study. Int J High Dilution Res2008, 7(22):36-38.

[20]Gazim ZC, Ferreira FBP, Silva AV, Bolognese KC, Merlini E, Messa V, Jesus RA, Coutinho CA, Silva LCM:Efficiency of tick biotherapic on the control of infestation by Rhipicephalus (Boophilus) microplusin Dutch dairy cows. Int J High Dilution Res2010, 9(33):156-164.

[21] Signoretti RD, Veríssimo CJ, Souza FHM, Oliveira EM, Dib V: Aspectos produtivos e sanitários de vacas mestiças leiteiras tratadas com produtos homeopáticos. Arq do Inst de Biol2010, 77(4):625-633.

[22] Deffune G, Oliveira WC (2011): Sistemas Orgânicos versus Convencionais no Controle de Ectoparasitas em Bovinocultura Leiteira Sustentável.Available at www.mda.gov.br/o/893437

[23] Costa-Júnior LM, Furlon J: Efficiency of sulphur in garlic extract and non-sulphur homeopathy in the control of the cattle tick Rhipicephalus (Boophilus) microplus. Med and Vet Entomol 2011, 25:7-11.

[24] Kossak-Romanach A: Homeopatia em 1000 conceitos. São Paulo: Elcid; 1984.

[25] Ortega P: S. Introducción a la medicina homeopática: teoria y técnica. México; 1994.

[26] Aleixo DL, Pupulin ART, Ferraz FN, Falkowski GJS, Gomes ML, Araujo SM: Bioterápico: diferentes esquemas de tratamento produzem efeitos diversos na infecção experimental pelo Trypanosoma cruzi. In: Proceedings of I Congresso Sul Americano de Farmácia, Maringá: Universidade Estadual de Maringá, 2010.

[27] Aleixo DL, Ferreira EC, Braga CF, Lopes CR, Falkowski GJS, Sandri PF, Araújo SM: Biotherapic T. cruzi 17DH when continuously used clinically improves mice infected with Trypanosoma cruzi. Int J High Dilution Res2011a, 10(36):134-137.

[28]Aleixo DL, Ferreira EC, Braga CF, Brustolin CF, Gomes ML, Pupulin ART, Araújo SM: Higher frequency of administration of biotherapicT. cruzi17DH decreases parasitemia and increases survival in mice infected with Trypanosoma cruzi. Int J High Dilution Res2011b; 10(36):163-166. 
[29]Aleixo DL, Braga CF, Moreira NM, Massini PF, Brustolin CF, Ferraz FN, Araújo SM: Influence of age and ways of treatment in the parasitemia in mice infected with Trypanosoma cruzi treated with high potency biotherapy. Int J High Dilution Res2011,10(36):138-141.

[30] Almeida BM, Pinto LF: Homeopathic treatment of Oesofagostomosis in Beef in State of Mato GrossoBrazil.Homeopat Bras 2002, 8(1):5-8.

[31] Rocha RA, Pacheco RDL, Amarante AFT: Efficacy of homeopathic treatment against natural infection of sheep by gastrointestinal nematodes. Rev Bras de Parasitol Vet2006, 15(1):23-27.

[32] Zacharias F, Guimarães JE, Araújo RR, Almeida MAO, Ayres MCC, Bavia ME, Mendonça-Lima FW: Effect of homeopathic medicines on helminth parasitism and resistance of Haemonchus contortus infected sheep.Homeopathy2008, 97:145-151.

[33] Andrade GM, Moura MS, Barbosa FC: Eficácia do produto homeopático Verm 100 no controle da verminose ovina: resultados parciais. PUBVET2011, 5(8).

[34]Sukul NC, Ghosh S, Sinhababu SP: Reduction in the number of infective Trichinella spiralis Larvae in mice by use of homeopathic drugs. Forsch Komplementmed 2005, 12(4).

[35] Silva AS, Faccio L, Otto MA, Ripoli FL, Monteiro SG, Sharom A: Homeopatia no tratamento de camundongos (Mus musculus) naturalmente infectados por Giardia muris. Cad de Pesq série Biol2007a, 20(1):15-21.

[36] Braga CF, Guilherme ALF, Aleixo DL, Falkowski GJS, Gois MB, Moreira NM, Araujo SM: Screening de potências de Bioterápico de Toxoplasma gondii em camundongos tratados pré infecção. In: Proceedings of I Congresso Sul Americano de Farmácia, Universidade Estadual de Maringá, Maringá, 2010.

[37] Malagutti CE, Freire MTA, Salgado WO, Murayama AG, Salgado AC, Lobão AO (2008): Toxoplasmose: Recuperação da visão pela Homeopatia (descrição de dois casos clínicos). [http://www.cesaho.com.br/]

[38] Almeida LR, Campos COM, Herrera HM, Bonamin LV, Fonseca AH: Effects of homeopathy in mice experimentally infected with Trypanosoma cruzi.Homeopathy 2008, 97 (2):57-8.

[39] Ferraz FN, Aleixo DL, Araujo SM, Gonçalves VA: Avaliação preliminar do efeito de bioterápico 7dH em diferentes esquemas terapêuticos sobre a infecção pelo Trypanosoma cruzi. In: Proceedings of Congresso Sul Americano de Farmácia , Maringá: Universidade Estadual de Maringá, 2010.

[40] Sandri PF, Falkowski GJS, Hernandes L, Dalálio MMO, Aleixo DL, Gomes ML, Nascimento-Júnior AD, Moliterno RA, Araújo SM: Biotherapic of Trypanosoma cruzi17d increases apoptosis in experimentally infected mice. Int J High Dilution Res2011a, 10(36):110-114.

[41]Sandri PF, Falkowski GJS, Nascimento-JúniorAD, Spack M, Moreira NM, Toledo MJO, Abreu-Filho B, Gabriel M, Araújo SM: Biotherapic of Trypanosoma cruzi17x controlled histopathological alterations in mice infected by this protozoon. Int J High Dilution Res2011b, 10(36):119-124.

[42]Bonamin LV, Endler PC: Animal model of studying homeopathy and high dilutions.Homeopathy 2010, 99:37-50. 
[43]Endler PC, Thieves K, Reich R, Matthiessen PF, Bonamin L, Scherr C, Baumgartner S: Repetitions of fundamental research models for homeopathically prepared dilutions beyond 10-23: a bibliometric study. Homeopathy2010, 99: 25-36.

[44]Lira-Salazar G, Marines-Montiel L, Torres-Monzón J, Hernandéz- Hernandéz F, Salas-Benito JS: Effects of homeopathic medications Eupatorium perfoliatum and Arsenicum album on parasitemia of Plasmodium berghei-infected mice. Homeopathy 2006, 95(4):223-8.

[45]Chaudhuri S, Varshney JP: Clinical management of babesiosis in dogs with homeopathic Crotalushorridus200C. Homeopathy2007,96:90-94.

[46]Aleixo DL, Ferraz FN, Melo CS, Gomes ML, Toledo MJ, Kaneshima EN, Bersani-Amado CA, Araújo SM: Changes of RAPD profile of Trypanosoma cruzi II with Canova and Benznidazole. Homeopathy 2008, 97:5964.

[47]Silva AS, Oliveira CB, Zanette RA, Monteiro IG: Homeopathy in the control of Trypanosoma evansi in experimentally infected rats. EstemBiol 2009, 31(73):123-7.

[48] Sandri P, Martins N, Nascimento-Júnior AD, Spack M, Gomes ML, Toledo MJO, Araújo SM: Influência da idade sobre o efeito de um bioterápico em infecção experimental por Trypanosoma cruzi. Br Hom J2009, 11(1):7-8.

[49] Ferraz FN, Sandri P, Aleixo DL, Nascimento-Junior AD, Spack M, Gomes ML, Toledo MJO, Araújo SM: O efeito de diferentes potências de bioterápico de Trypanosoma cruzi na infecção experimental. $\mathrm{Br}$ Hom J2009, 11(1):5-6.

[50]Billotti C, Ferraz FN, Nascimento-Júnior AD, Spack M, Panza S, Alvares AAA, Gomes ML, Toledo MJO, Martinichen JC, Araújo SM: Parâmetros hematológicos em camundongos infectados pelo Trypanosoma cruzi e tratados com bioterápicos.Br Hom J2009, 11(1):9-10.

[51] Sandri PF: Influência da idade sobre os efeitos do bioterápico $17 \mathrm{dH}$ na infecção de camundongos pelo Trypanosoma cruzi. Dissertação - Universidade Estadual de Maringá, Maringá; 2010.

[52]Pupulin AR, Araujo SM, Toledo MJ, Gomes ML, Takejima E, Cuman RK, bersani-Amado CA: Canova medication modifies parasitological parameters in mice infected with Trypanosoma cruzi. ExpParasitol2010, 126(4):435-40.

[53] Braga CF, Drozino RN, Moreira NM, Aleixo DL, Araújo SM: Effect of 7DH biotherapic of Toxoplasma gondii in mice infected with the protozoan. Int J High Dilution Res 2011b, 10(36):147-151.

[54]Ferraz FN, Gonçalves VA, Aleixo DL, Mizutani AS, Araújo SM: Effect of biotherapy T. cruzi 7x in several therapeutic schemes on experimental infection by Trypanosoma cruzi. Int J High Dilution Res2011a, 10(36):125-127.

[55]Ferraz FN, Gonçalves VA, Aleixo DL, Mizutani AS, Araújo SM:Evaluation of biotherapies T.cruzi 15x, 16x, 17x and "potency chords" in experimental infection by Trypanosoma cruzi. Int J High Dilution Res2011b, 10(36):130-133. 
[56] Braga CF, Falkowski GJS, Moreira NM, Aleixo DL, Araújo SM: Biotherapic 200 DH reduces cerebral parasitism in mice infected with Toxoplasma gondii. Int J High Dilution Res2011a, 10(36):158-162.

[57]Ferreira EC, Braga CF, Massini PF, Drozino RN, Moreira NM, Aleixo DL, Guilherme ALF, Araújo,S.M. Homeopathy: statistical significance versus the sample size in experiments with Toxoplasma gondii.Int $\mathrm{J}$ High Dilution Res2011,10(36):115-118.

[58] Pesquisa homeopatica: homeopatia esplorado. Brasil: Instituto Homeopático François Lamasson 1994, $9(1): 1-25$.

\title{
Homeopatia em doenças parasitárias
}

\section{RESUMO}

Introdução: O uso de homeopáticos tem crescido devido o fato de que medicamentos convencionais algumas vezes não produzem o efeito esperado e também devido os seus efeitos indesejados que comprometem a adesão ao tratamento. Alguns trabalhos mostram os benefícios da utilização de medicamentos ultradiluídos no tratamento de doenças infecciosas. Objetivo: Esta revisão é uma discussão crítica sobre os aspectos da homeopatia, o estado atual da experimentação veterinária e o uso de medicamentos ultradiluídos nas infecções e doenças parasitárias. Os principais aspectos dos efeitos, esquemas de tratamento e/ou dinamizações utilizadas nos diferentes modelos são discutidos. Metodologia: Uma revisão de artigos publicados desde 2000 em revistas indexadas nos bancos de dados PubMed e Scielo e revistas especializadas foi utilizada para pesquisa das palavras-chave: parasitoses/ homeopatia e parasitoses/ ultradiluídos. Resultados: Experimentos recentes demonstraram o efeito biológico dos medicamentos ultradiluídos nas infecções parasitárias, com redução no número de parasitos e melhora da condição clínica nos animais tratados. Alguns artigos apresentaram problemas na descrição da metodologia o que pode comprometer a reprodutibilidade dos experimentos. Conclusão: $\mathrm{O}$ conhecimento da homeopatia depende da credibilidade dos grupos de pesquisa. Embora nos últimos anos a pesquisa em homeopatia tenha apresentado um claro desenvolvimento, tanto na implantação de metodologias mais consistentes quanto na descrição dos dados e métodos publicados, muito ainda deve ser melhorado neste campo. Descrições precisas e detalhadas poderiam contribuir para o avanço do uso da homeopatia, o que poderia beneficiar a comunidade em geral, na prática, a partir destes resultados.

Palavras-Chave: homeopatia, infecções parasitárias, Medicina Complementar e Alternativa

\section{Homeopatía en parasitosis}

\author{
RESUMEN
}

Introducción: El uso de medicamentos homeopáticos viene aumentado, en parte porque los convencionales a veces no producen los efectos deseados y en parte porque los efectos colaterales de estos comprometen la adhesión del paciente al tratamiento. Varios estudios demostraron beneficio con el uso de medicamentos homeopáticos en el tratamiento de enfermedades infecciosas. Objetivos: El objetivo de esta revisión fue someter a análisis crítico varios aspectos 
de la homeopatía, el estado presente de la experimentación veterinaria y el uso de altas diluciones de medicamentos en enfermedades infecciosas y parasitarias. Son discutidos aspectos principales de los efectos, regímenes terapéuticos y/o dinamizaciones utilizadas en varios modelos. Métodos: Se realizó una revisión de artículos publicados a partir del 2000 en periódicos indexados en las bases de datos SciELO y PubMed usando los descriptores "parasitosis/homeopatía" y "parasitosis/altas diluciones". Resultados: Varios estudios experimentales recientes demostraron efectos biológicos de medicamentos altamente diluidos en parasitosis, resultando en disminución del número de parásitos y mejoría del estado clínico de los animales afectados. En varios artículos, sin embargo, la descripción de la metodología es problemática, lo que compromete la reproductibilidad de los experimentos. Conclusión: El reconocimiento de la homeopatía depende de la credibilidad de los investigadores. Aunque la investigación en homeopatía se ha desarrollado notablemente en los últimos años, tanto en la implementación de metodologías más consistentes, como en la descripción de dados y métodos, mejorías son aun necesarias. Descripciones precisas y detalladas contribuirán al progreso del uso de la homeopatía de modo que resulte en beneficio práctico para la sociedad en general.

Palabras-clave: homeopatía, parasitosis, MAC (medicina alternativa y complementaria).

\section{(c)) BY-No-ND Licensed to GIRI}

Support: This work was supported by PROAP/ CAPES and FundaçãoAraucária- Paraná, Brazil.

Conflict of interest: authors declare there is no conflict of interest

Received: October 09th 2013 ; Revised: February26th, 2014; Published: March 3025th 2014.

Correspondence author: Denise Lessa Aleixo, deniseparasito@gmail.com

How to cite this article: Aleixo DL, Bonamin LV, Ferraz FN, da Veiga FK, de Araújo SM. Homeopathy in parasitic diseases [review]. Int J High Dilution Res [online]. 2014 [cited YYYY Month dd]; 13(46): 13-27. Available from: http://www.feg.unesp.br/ ojs/index.php/ijhdr/article/view/683/688 